Journal of Clinical Investigation

Vol. 42, No. 6, 1963

\title{
IN VITRO PYRROLE AND PORPHYRIN SYNTHESIS IN LEAD POISONING AND IRON DEFICIENCY*
}

\author{
By HERBERT C. LICHTMAN AND FELIX FELDMAN
}

(From the Departments of Medicine and Pediatrics, State University of New York, Downstate

Medical Center; Kings County Hospital Center; and Maimonides Hospital, Brooklyn, N. Y.)

(Submitted for publication June 28, 1962; accepted February 13, 1963)

Anemia occurs frequently in man with lead intoxication. The degree of anemia varies considerably, but is often quite severe, especially in children. Hypochromia, basophilic stippling, and siderocytosis characterize the erythrocytes. There is evidence in favor of both augmented hemolysis (1) and impaired hemoglobin synthesis as operating mechanisms in the pathogenesis of the anemia.

The finding in lead poisoning of increased free erythrocyte porphyrins has long been known. The early literature has recently been reviewed (2). The presence of intracellular iron granules (3) and the excessive urinary excretion of $\delta$ aminolevulinic acid and coproporphyrin III $(4,5)$ all suggest disturbances in the biosynthesis of heme.

As a result of the efforts of a number of investigators, whose work is summarized in Figure 1, a pathway for the biosynthesis of heme has been outlined (6-23).

The enzymes necessary for the complete in vitro synthesis of heme from glycine and succinate cannot be demonstrated in the non-nucleated, nonreticulated erythrocyte (24). With $\delta$-aminolevulinic acid as substrate, however, the enzymes necessary for conversion to porphobilinogen, uroporphyrin, and coproporphyrin remain active in the mature erythrocyte (25).

The present study was undertaken to discover whether porphobilinogen and porphyrin synthesis from $\delta$-aminolevulinic acid was altered in lead poisoning and iron-deficiency anemia. Porphobilinogen and porphyrin production in vitro was assayed with $\delta$-aminolevulinic acid as substrate and hemolyzed erythrocytes of normal individuals and patients with lead poisoning and iron-deficiency anemia as sources of enzymes. In addition, the effect of glutathione on in vitro pyrrole

* Supported by U. S. Public Health Service grant H3877; presented in part before the Society for Pediatric Research, Atlantic City, N. J., May, 1961. synthesis was determined in the normal and the lead-poisoned erythrocyte.

\section{METHODS}

Blood was collected with heparin as the anticoagulant and kept at $0^{\circ} \mathrm{C}$ until incubation. Hemoglobin concentration, hematocrit, and erythrocyte, reticulocyte, nucleated erythrocyte, and leukocyte counts were determined on each specimen. The plasma was removed and the cells were washed twice with ice-cold $0.85 \%$ saline. The erythrocytes were then resuspended in enough cold $0.85 \%$ saline to restore the original volume. The measurements above were repeated on the resuspended erythrocytes, which were then lysed by rapid freezing and thawing twice.

$\delta$-Aminolevulinic acid dehydrase activity was determined by a modification of the method of Granick and Mauzerall (17). Hemolyzed erythrocytes were used as a source of enzyme instead of purified enzyme solution. Each incubation mixture contained $2 \mathrm{ml}$ of lysed erythrocyte suspension, including the ghosts, $1 \mathrm{ml}$ of $1 / 15 \mathrm{M}$ phosphate buffer at $\mathrm{pH} 7.2$, and $0.2 \mathrm{ml}$ of $0.1 \mathrm{M} \delta$-aminolevulinic acid. Control tubes were identical except that they contained $0.2 \mathrm{ml}$ of water in place of $\delta$-aminolevulinic acid.

The air was evacuated from each Thunberg tube containing the lysed cell suspension and buffer, and the tube was filled twice with nitrogen gas. $\delta$-Aminolevulinic acid or water was added to the incubation mixtures from the hollow glass stopper of the Thunberg tube just before incubation, which was accomplished in a shaking water bath at $37^{\circ} \mathrm{C}$ for 1 hour.

When glutathione was used, it was added in $0.01 \mathrm{M}$ concentration to the in vitro system and incubated at $37^{\circ} \mathrm{C}$ for 1 hour before $\delta$-aminolevulinic acid was added. Control mixtures of hemolyzed cells with phosphate buffer were also incubated at $37^{\circ} \mathrm{C}$ for 1 hour before the substrate was added. Incubation proceeded as above. The reaction was terminated at 1 hour by the addition of $10 \mathrm{ml}$ of trichloroacetic acid-mercuric chloride mixture. The precipitate was removed by centrifugation.

Porphobilinogen was determined by addition of modified Ehrlich's reagent. Optical density was read in a Beckman DU spectrophotometer at $553 \mu \mathrm{m}$ after 3 minutes. $\delta$-Aminolevulinic acid dehydrase activity was reported as $\mu$ moles porphobilinogen per hour of incubation per milliliter of packed erythrocytes ; the amount of porphobilinogen is the difference between the amounts accumulated with and without added $\delta$-aminolevulinic acid. 


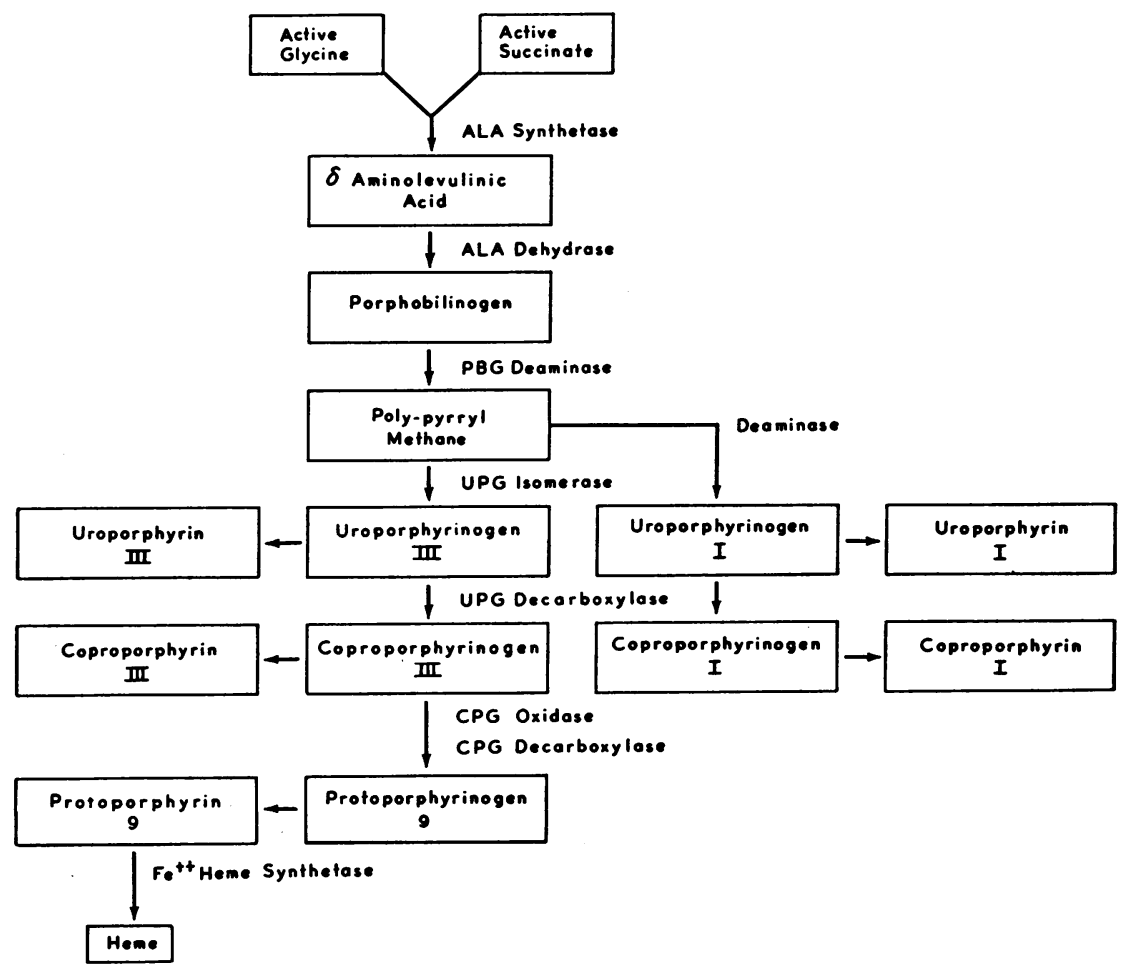

Fig. 1. Simplified schema for the biosynthesis of heme.

Uroporphyrin, coproporphyrin, and protoporphyrin de- under aerobic conditions in a shaking water bath at terminations. Blood was collected and hemolyzed as de- $37^{\circ} \mathrm{C}$. Control tubes contained $0.2 \mathrm{ml}$ of water in place scribed above. Incubation mixtures were the same as of $\delta$-aminolevulinic acid. above, but incubation was allowed to proceed for 4 hours Extraction, fractionation, and determination of copro-

TABLE I

$\delta$-Aminolevulinic acid dehydrase activity in normal patients

\begin{tabular}{|c|c|c|c|c|c|c|c|c|}
\hline \multirow[b]{2}{*}{ Patient } & \multicolumn{5}{|c|}{ Whole blood } & \multicolumn{2}{|c|}{ Incubation mixture } & \multirow[b]{2}{*}{ Activity* } \\
\hline & Hemoglobin & Hematocrit & Erythrocytes & $\begin{array}{l}\text { Reticu- } \\
\text { locytes }\end{array}$ & Leukocytes & $\begin{array}{l}\text { Reticu- } \\
\text { locytes }\end{array}$ & Leukocytes & \\
\hline & $\mathrm{g} / 100 \mathrm{ml}$ & $\%$ & $10^{6} / \mu l$ & $\begin{array}{c}\% \text { of erythro- } \\
\text { cytes }\end{array}$ & $/ \mu l$ & $\%$ & $/ \mu l$ & \\
\hline 1 & 14.5 & 44 & 5.10 & 1.0 & 12,500 & 0.8 & 2,800 & 229 \\
\hline 2 & 12.0 & 38 & 4.34 & 0.2 & 10,400 & 0.5 & 1,600 & 138 \\
\hline 3 & 14.5 & 46 & 4.93 & 0.4 & 5,400 & 0.4 & 400 & 55 \\
\hline 4 & 13.1 & 40 & 4.40 & 0.6 & 6,600 & 0.9 & 200 & 28 \\
\hline 5 & 15.0 & 47 & 5.26 & 1.4 & 14,000 & 1.2 & 1,300 & 209 \\
\hline 6 & 14.5 & 46 & 5.14 & 0.7 & 5,300 & 0.5 & 2,200 & 327 \\
\hline 7 & 13.3 & 39.5 & 4.69 & 1.1 & 7,150 & 0.5 & 700 & 133 \\
\hline 8 & 14.1 & 46.5 & 5.49 & 0.4 & 8,000 & 0.2 & 1,700 & 308 \\
\hline 9 & 15.4 & 47.5 & 5.36 & 0.7 & 9,250 & 0.3 & 50 & 234 \\
\hline 10 & 12.6 & 40.5 & 4.51 & 0.6 & 7,600 & 0.8 & 250 & 221 \\
\hline 11 & 13 & 39 & 4.96 & 0.8 & 5,900 & 0.8 & 1,900 & 199 \\
\hline 12 & 15.4 & 47 & 5.27 & 0.4 & 7,700 & 0.6 & 200 & 209 \\
\hline 13 & 13.7 & 43 & 5.04 & 0.2 & 8,150 & 0.4 & 2,000 & 111 \\
\hline 14 & 13.7 & 44 & 4.73 & 0.9 & 8,500 & 0.7 & 2,850 & 91 \\
\hline 15 & 13.7 & 42 & 4.78 & 0.3 & 6,600 & 0.1 & 1,000 & 219 \\
\hline 16 & 12.8 & 40 & 4.39 & 0.5 & 11,000 & 0.8 & 1,600 & 142 \\
\hline Mean & 13.8 & 43.1 & 4.9 & 0.6 & 8,394 & 0.6 & 1,300 & 178 \\
\hline
\end{tabular}

* $\delta$-Aminolevulinic acid dehydrase activity expressed as $\times 10^{-3}$ micromole of porphobilinogen synthesized per milliliter of packed red blood cells per hour of incubation. 
TABLE II

$\delta$-A minolevulinic acid dehydrase activity in iron-deficiency anemia

\begin{tabular}{|c|c|c|c|c|c|c|c|c|}
\hline \multirow[b]{2}{*}{ Patient } & \multicolumn{5}{|c|}{ Whole blood } & \multicolumn{2}{|c|}{ Incubation mixture } & \multirow[b]{2}{*}{ Activity* } \\
\hline & Hemoglobin & Hematocrit & Erythrocytes & $\begin{array}{l}\text { Reticu- } \\
\text { locytes }\end{array}$ & Leukocytes & $\begin{array}{l}\text { Reticu- } \\
\text { locytes }\end{array}$ & Leukocytes & \\
\hline & $\mathrm{g} / 100 \mathrm{ml}$ & $\%$ & $10^{6} / \mu l$ & $\begin{array}{c}\text { \% of erythro- } \\
\text { cytes }\end{array}$ & $/ \mu l$ & $\%$ & $/ \mu l$ & \\
\hline 1 & 4.5 & 21 & 3.62 & 0.5 & 8,600 & 1.4 & 4,150 & 245 \\
\hline 2 & 5.6 & 23.5 & 3.74 & 0.9 & & 0.3 & & 347 \\
\hline 3 & 5.0 & 22.5 & 3.38 & 2.0 & 9,300 & 1.2 & 2,400 & 464 \\
\hline 4 & 7.0 & 28.5 & 3.88 & 5.3 & 5,400 & 1.0 & 2,800 & 209 \\
\hline 5 & 5.1 & 20 & 3.31 & 0.3 & 6,300 & 0.1 & 1,700 & 50 \\
\hline 6 & 7.1 & 28 & 4.78 & 0.3 & 11,500 & 0.2 & 1,900 & 69 \\
\hline 7 & 9.6 & 30 & 4.79 & 0.7 & 10,450 & 0.4 & 4,200 & 134 \\
\hline 8 & 8.5 & 32 & 4.48 & 0.4 & 12,500 & 0.2 & 2,800 & 197 \\
\hline 9 & 6.4 & 23.5 & 3.08 & 0.6 & 11,300 & 0.8 & 8,950 & 264 \\
\hline Mean & 6.5 & 25.4 & 3.89 & 1.2 & 9,417 & 0.6 & 3,612 & 219 \\
\hline
\end{tabular}

${ }^{*} \delta$-Aminolevulinic acid dehydrase activity expressed as $\times 10^{-3}$ micromole of porphobilinogen per milliliter of packed red blood cells per hour of incubation.

TABLE III

$\delta$-Aminolevulinic acid dehydrase activity in plumbism

\begin{tabular}{|c|c|c|c|c|c|c|c|c|}
\hline \multirow[b]{2}{*}{ Patient } & \multicolumn{5}{|c|}{ Whole blood } & \multicolumn{2}{|c|}{ Incubation mixture } & \multirow[b]{2}{*}{ Activity* } \\
\hline & Hemoglobin & Hematocrit & Erythrocytes & $\begin{array}{l}\text { Reticu- } \\
\text { locytes }\end{array}$ & Leukocytes & $\begin{array}{l}\text { Reticu- } \\
\text { locytes }\end{array}$ & Leukocytes & \\
\hline & $\mathrm{g} / 100 \mathrm{ml}$ & $\%$ & $10^{6} / \mu l$ & $\begin{array}{c}\% \text { of erythro- } \\
\text { cytes }\end{array}$ & $/ \mu l$ & $\%$ & $/ \mu l$ & \\
\hline 1 & 8.6 & 34 & 5.1 & 2.2 & 8,150 & 2.0 & 1,400 & 31 \\
\hline 2 & 11.2 & 37 & 4.38 & 0.6 & 5,500 & 0.2 & 1,850 & 137 \\
\hline 3 & 8.8 & 35 & 5.3 & 1.2 & 16,000 & 0.4 & 4,400 & 72 \\
\hline 4 & 5.8 & 26 & 5.2 & 1.4 & 6,900 & 0.1 & 1,100 & 152 \\
\hline 5 & 8.0 & 31 & 4.03 & 0.9 & 44,800 & 0.3 & 1,600 & 105 \\
\hline 6 & 10.6 & 37 & 4.92 & 0.4 & 6,100 & 0.1 & 1,300 & 182 \\
\hline 7 & 8.8 & 33.5 & 4.46 & 0.9 & 10,000 & 0.4 & 2,400 & 85 \\
\hline 8 & 11.0 & 40 & 5.88 & 0.5 & 10,950 & 0.2 & 400 & 17 \\
\hline 9 & 9.2 & 34.5 & 5.42 & 0.3 & 12,500 & 0.2 & 1,100 & 58 \\
\hline 10 & 11.2 & 35 & 4.50 & 0.9 & 5,650 & 0.4 & 500 & 88 \\
\hline 11 & 8.8 & 32 & 4.76 & 1.6 & 14,480 & 1.8 & 2,500 & 53 \\
\hline Mean & 9.3 & 34.1 & 4.9 & .99 & 12,816 & 0.6 & 1,086 & 89 \\
\hline
\end{tabular}

${ }^{*} \delta$-Aminolevulinic acid dehydrase activity expressed as $\times 10^{-3}$ micromole of porphobilinogen synthesized per milliliter of packed red blood cells per hour of incubation.

porphyrin and protoporphyrin followed a modification of the procedures of Schwartz and Wikoff (26). Uroporphyrin was determined by the method of Dresel and Tooth (27) as outlined by Dresel and Falk (28). On a number of occasions, after the complete extraction of coproand protoporphyrins with $15 \% \mathrm{HCl}$, the ethyl acetate layer was tested for the presence of porphyrinogens. After shaking with a solution of $I_{2}$ (29), no additional porphyrin was found, whether or not glutathione had been added. Production of porphyrins was expressed in micrograms per $100 \mathrm{ml}$ erythrocytes. The porphyrins reported represent the differences between the control tubes and those with $\delta$-aminolevulinic acid.

\section{RESULTS}

$\delta$-Aminolevulinic acid dehydrase activity. Hemolyzed erythrocytes were used rather than

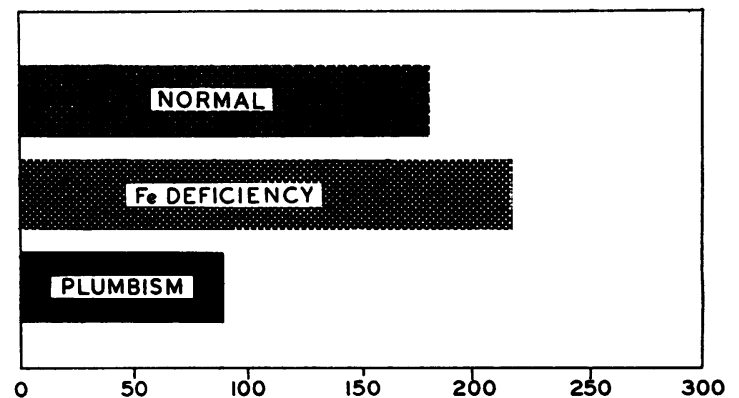

Fig. 2. $\delta$-AMINOLEvUlinic ACID DEHYdRASE ACtivity IN HEMOLYZED ERYTHROCYTES--NORMAL, IRON-DEFICIENT, AND LEAD-POISONED. Activity is given in micromole $\times 10^{-3}$ of porphobilinogen per hour of incubation per milliliter of packed erythrocytes. 
TABLE IV

Porphyrin synthesis in normal patients

\begin{tabular}{|c|c|c|c|c|c|c|c|c|c|}
\hline \multirow[b]{3}{*}{ Patient } & \multicolumn{2}{|c|}{ Incubation mixture } & \multicolumn{7}{|c|}{ Porphyrins } \\
\hline & \multirow{2}{*}{$\begin{array}{l}\text { Reticu- } \\
\text { locytes }\end{array}$} & \multirow[b]{2}{*}{ Leukocytes } & \multicolumn{3}{|c|}{ Control* } & \multicolumn{4}{|c|}{ Experimental $\dagger$} \\
\hline & & & Uro- & Copro- & Proto- & Uro- & Copro- & Proto- & Total \\
\hline & $\%$ & $/ \mu l$ & \multicolumn{7}{|c|}{$\mu \mathrm{g} / 100 \mathrm{ml}$ erythrocytes } \\
\hline 1 & 0.4 & 200 & 2 & 3 & 166 & 492 & 391 & 135 & 1,018 \\
\hline 2 & 0.8 & 1,600 & $1 \overline{5}$ & 2 & 70 & 488 & 883 & 64 & 1,435 \\
\hline 3 & 0.4 & 2,200 & 16 & $1 \overline{2}$ & 107 & 244 & 230 & 40 & 514 \\
\hline 4 & 0.2 & 1,900 & 16 & 3 & 59 & 758 & 223 & 27 & 1,008 \\
\hline 5 & 0.4 & 4,700 & 12 & 4 & 56 & 572 & 268 & 13 & 853 \\
\hline 6 & 0.4 & 2,100 & 7 & 11 & 34 & 638 & 859 & 46 & 1,543 \\
\hline 7 & 0.4 & 2,500 & 3 & 3 & 58 & 760 & 957 & 90 & 1,807 \\
\hline 8 & 0.4 & 4,300 & 8 & 2 & 85 & 882 & 896 & 110 & 1,888 \\
\hline 9 & 0.4 & 1,700 & 4 & 5 & 31 & 180 & 698 & 82 & 960 \\
\hline 10 & 0.4 & 1,000 & 3 & 7 & 35 & 760 & 1,168 & 71 & 1,999 \\
\hline 11 & 0.6 & 3,800 & 24 & 3 & 63 & 436 & 1,014 & 72 & 1,522 \\
\hline 12 & 0.2 & 550 & 18 & 10 & 16 & 176 & 557 & 83 & 816 \\
\hline Mean & 0.4 & 2,213 & 10.7 & 5.5 & 65 & 532 & 679 & 69 & 1,280 \\
\hline
\end{tabular}

* Water was used in place of $\delta$-aminolevulinic acid.

$\dagger \delta$-Aminolevulinic acid was added to the incubation mixture; values represent the net amount of porphyrin found after subtraction of control values.

purified enzyme. However, the amount of porphyrins formed in 1 hour under anaerobic conditions in this type of system is small (30).

Data, derived from 16 normal samples, on the activity of the enzyme necessary for conversion of $\delta$-aminolevulinic acid to porphobilinogen are presented in Table I. Hematologic information on each blood sample and the reticulocyte and leukocyte counts on the incubation mixtures are also included. Hemoglobin concentration varied from 12.0 to $15.4 \mathrm{~g}$ per $100 \mathrm{ml}$, with a mean of $13.8 \%$. Hematocrit values ranged from 38 to $47.5 \%$, with a mean of 43.1. Erythrocyte counts also were in the normal range, from $4.34 \times 10^{\circ}$ to $5.49 \times 10^{\circ}$ cells per $\mathrm{mm}^{3}$, with a mean of $4.9 \times 10^{6}$. The mean reticulocyte count was $0.6 \%$, with a range of from 0.2 to $1.4 \%$. Reticulocyte counts in the incubation mixtures ranged from 0.1 to $1.2 \%$, again with a mean of $0.6 \%$. The activity of $\delta$ aminolevulinic acid dehydrase varied widely in this group, from $28 \times 10^{-3}$ to $327 \times 10^{-3}$, $\mu$ mole porphobilinogen per $\mathrm{ml}$ packed erythrocytes per hour of incubation, with a mean of $178 \times 10^{-3}$.

Results obtained in erythrocytes from nine chil-

TABLE V

Porphyrin synthesis in iron-deficiency anemia

\begin{tabular}{|c|c|c|c|c|c|c|c|c|c|}
\hline \multirow[b]{3}{*}{ Patient } & \multirow{2}{*}{\multicolumn{2}{|c|}{ Incubation mixture }} & \multicolumn{7}{|c|}{ Porphyrins } \\
\hline & & & \multicolumn{3}{|c|}{ Control* } & \multicolumn{4}{|c|}{ Experimentalt } \\
\hline & $\begin{array}{l}\text { Reticu- } \\
\text { locytes }\end{array}$ & Leukocytes & Uro- & Copro- & Proto- & Uro- & Copro- & Proto- & Total \\
\hline & $\%$ & $/ \mu l$ & \multicolumn{7}{|c|}{$\mu \mathrm{g} / 100 \mathrm{ml}$ erythrocyles } \\
\hline 1 & 1.4 & 4,150 & 0 & 4 & 215 & 0 & 170 & 171 & 341 \\
\hline 2 & 0.3 & & 6 & 8 & 316 & 216 & 447 & 106 & 769 \\
\hline 3 & 1.2 & 2,400 & 13 & 2 & 620 & 52 & 67 & 58 & 177 \\
\hline 4 & 1.0 & 2,800 & 14 & 7 & 354 & 158 & 1,433 & 300 & 1,891 \\
\hline 5 & 0.1 & 1,700 & 51 & 18 & 192 & 66 & 474 & 39 & 579 \\
\hline 6 & 0.2 & 1,900 & 39 & 24 & 385 & 82 & 381 & 60 & 523 \\
\hline 7 & 0.4 & 4,200 & 10 & 10 & 101 & 96 & 383 & 206 & 685 \\
\hline 8 & 0.2 & 2,800 & 9 & 18 & 350 & 156 & 523 & 131 & 810 \\
\hline 9 & 0.8 & 8,950 & 20 & 7 & 133 & 194 & 812 & 483 & 1,489 \\
\hline Mean & 0.6 & 3,622 & 17.0 & 11 & 296 & 128 & 521 & 173 & 807 \\
\hline
\end{tabular}

* Water was used in place of $\delta$-aminolevulinic acid.

$\dagger \delta$-Aminolevulinic acid was added in incubation mixture; values represent the net amount of porphyrin found after subtraction of control values. 
TABLE VI

Porphyrin synthesis in plumbism

\begin{tabular}{|c|c|c|c|c|c|c|c|c|c|}
\hline \multirow[b]{3}{*}{ Patient } & \multirow{2}{*}{\multicolumn{2}{|c|}{ Incubation mixture }} & \multicolumn{7}{|c|}{ Porphyrins } \\
\hline & & & \multicolumn{3}{|c|}{ Control* } & \multicolumn{4}{|c|}{ Experimental $\dagger$} \\
\hline & $\begin{array}{l}\text { Reticu- } \\
\text { locytes }\end{array}$ & \multirow{2}{*}{$\frac{\text { Leukocytes }}{/ \mu l}$} & Uro- & Copro- & Proto- & Uro- & Copro- & Proto- & Total \\
\hline & $\%$ & & \multicolumn{7}{|c|}{$\mu \mathrm{g} / 100 \mathrm{ml}$ erythrocyles } \\
\hline 1 & 2.0 & 1,400 & 20 & & 1,368 & 32 & 360 & 0 & 392 \\
\hline 2 & 0.2 & 1,850 & 18 & 8 & 95 & 107 & 398 & 120 & 525 \\
\hline$\overline{3}$ & 0.5 & 4,400 & 37 & 13 & 1,622 & 156 & 198 & 105 & 459 \\
\hline 4 & 0.1 & 1,100 & 59 & 23 & 2,770 & 98 & 0 & 202 & 300 \\
\hline 5 & 0.3 & 1,600 & 7 & 17 & 1,525 & 22 & $\mathbf{0}$ & 160 & 182 \\
\hline 6 & 0.1 & 1,300 & 6 & 8 & 212 & 80 & 399 & 0 & 429 \\
\hline 7 & 0.4 & 2,400 & 29 & 37 & 1,520 & 0 & 416 & 80 & 496 \\
\hline 8 & 0.2 & 400 & 44 & 57 & 1,940 & 16 & 342 & 20 & 378 \\
\hline 9 & 0.2 & 1,100 & 29 & 14 & 1,890 & 0 & 323 & 190 & 513 \\
\hline 10 & 1.8 & 2,500 & 14 & 5 & 1,237 & 10 & 199 & 0 & 209 \\
\hline Mean & 0.6 & 1,686 & 26.3 & 221 & 1,418 & 52 & 259 & 88 & 388 \\
\hline
\end{tabular}

* Water was used in place of $\delta$-aminolevulinic acid.

$\dagger \delta$-Aminolevulinic acid was added to the incubation mixture; values represent the net amount of porphyrin found after subtraction of control values.

dren with iron-deficiency anemia are presented in Table II. The hemograms reveal the expected findings of hypochromic microcytic anemia in all cases. Mean values were: hemoglobin concentration $6.5 \mathrm{~g}$ per $100 \mathrm{ml}$, hematocrit $25.4 \%$, erythrocyte count $3.89 \times 10^{\circ}$ cells per $\mathrm{mm}^{3}$, and reticulocyte count $1.2 \%$ in whole blood and $0.6 \%$ on the cells used in the incubation mixture. Again the $\delta$-aminolevulinic acid dehydrase activity varied widely, from $50 \times 10^{-3}$ to $464 \times 10^{-3} \mu$ mole porphobili-

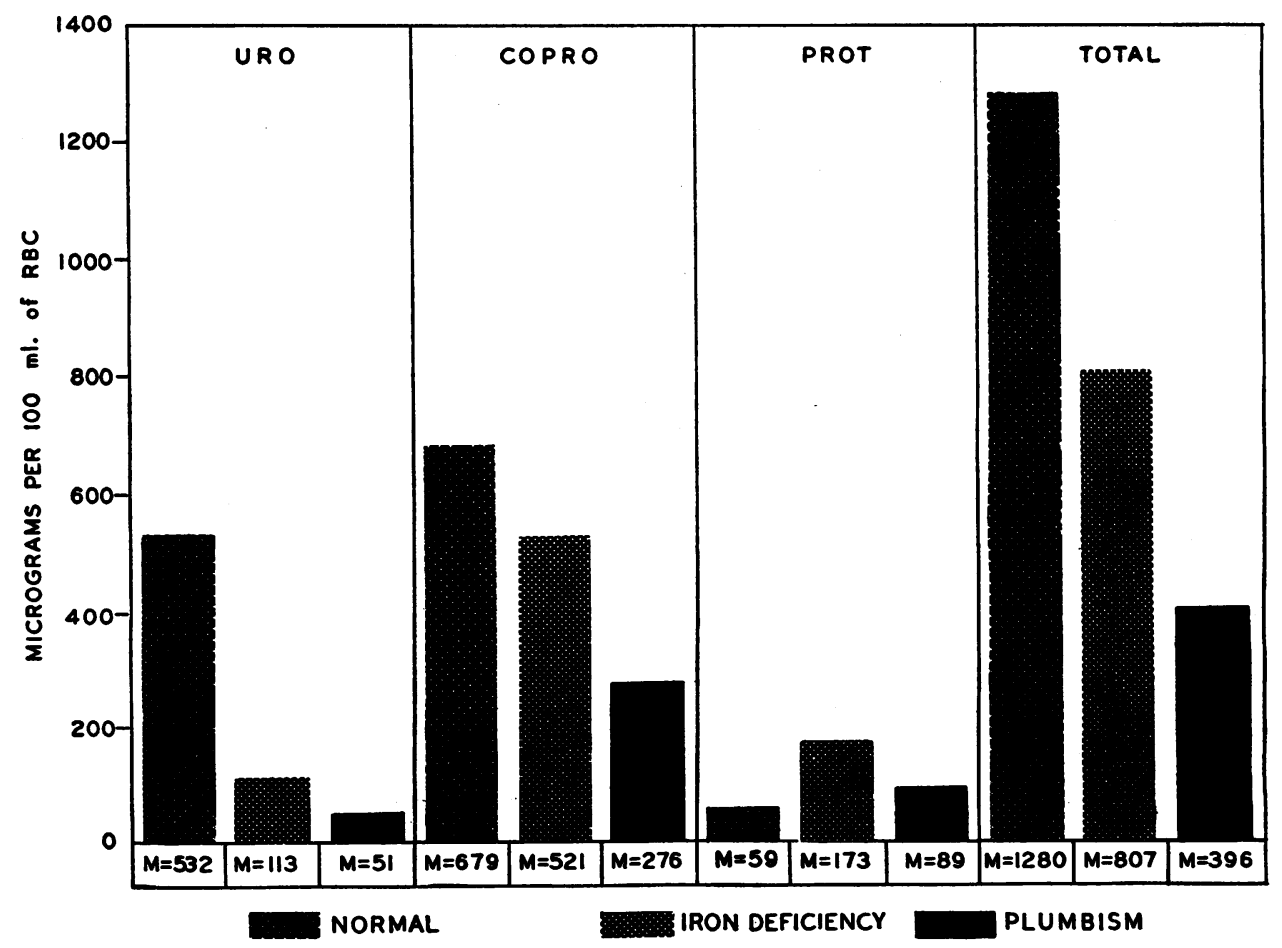

FIG. 3. SYNTHESIS OF PORPHYRIN AND PORPHYRINOGEN IN HEMOLYZED ERYTHROCYTESNORMAL, IRON-DEFICIENT, AND LEAD-POISONED. 
nogen per $\mathrm{ml}$ packed erythroctyes per hour, with a mean of $219 \times 10^{-3}$. These results were not significantly different from the normal.

Results obtained from erythrocytes of eleven children with lead poisoning are tabulated in $\mathrm{Ta}$ ble III. All of the patients had some degree of anemia. Hemoglobin concentrations ranged from 5.8 to $11.2 \mathrm{~g}$ per $100 \mathrm{ml}$, with a mean of 9.3. The mean hematocrit was $34 \%$, the mean erythrocyte count $4.9 \times 10^{6}$ cells per $\mathrm{mm}^{3}$, the mean reticulocyte count $0.99 \%$ in whole blood and $0.6 \%$ on cells used in the incubation mixtures. The range of values for $\delta$-aminolevulinic acid dehydrase activity was much lower in this group, $17 \times 10^{-3}$ to $182 \times 10^{-3}$ umole porphobilinogen per $\mathrm{ml}$ packed erythrocytes per hour, with a mean of 89 $\times 10^{-3}$. Comparison of the means in the three groups (Figure 2) indicates that the activity of $\delta$-aminolevulinic acid dehydrase in lead poisoning is significantly lower than the normal or the irondeficiency values. The $p$ value for the difference between the normal group and the group with plumbism was between .05 and .01 ; for the difference between the groups with iron deficiency and plumbism, $\mathrm{p}$ was less than .01 .

Porphyrin and porphyrinogen synthesis from $\delta$-aminolevulinic acid. The results of experiments designed to measure the synthesis of porphyrins in the three clinical groups are summarized in
Tables IV, V, and VI. Hemograms in each case are not listed because they are the same as those listed previously. There appears to be an inverse relationship between the erythrocyte porphyrins in the controls and the amount of porphyrins synthesized. The normal erythrocytes producing the largest amount of porphyrins in vitro had the lowest amount of free control porphyrins, whereas the lead-poisoned erythrocytes producing the least amount of porphyrins from $\delta$-aminolevulinic acid had the highest levels of free control porphyrins. This apparent paradox will be discussed subsequently. The greatest discrepancy in porphyrin production was detected in the uroporphyrin fraction.

The mean of the values for uroporphyrin synthesis by the normal group was $532 \mu \mathrm{g}$ per $100 \mathrm{ml}$ erythrocytes, with a range of 176 to $882 \mu \mathrm{g}$. The mean in the iron-deficiency group was $128 \mu \mathrm{g}$ per $100 \mathrm{ml}$ erythrocytes, with a range of 0 to $216 \mu \mathrm{g}$. In the lead-poisoned group, the mean was $52 \mu \mathrm{g}$ per $100 \mathrm{ml}$ erythrocytes, with a range of 0 to $156 \mu \mathrm{g}$.

Coproporphyrin accumulation was also highest when normal erythrocytes were used as a source of enzyme. The mean was $679 \mu \mathrm{g}$ per $100 \mathrm{ml}$ erythrocytes, with a range of 230 to $1,168 \mu \mathrm{g}$. Coproporphyrin production was slightly lower in the iron-deficiency group, with a mean of $521 \mu \mathrm{g}$

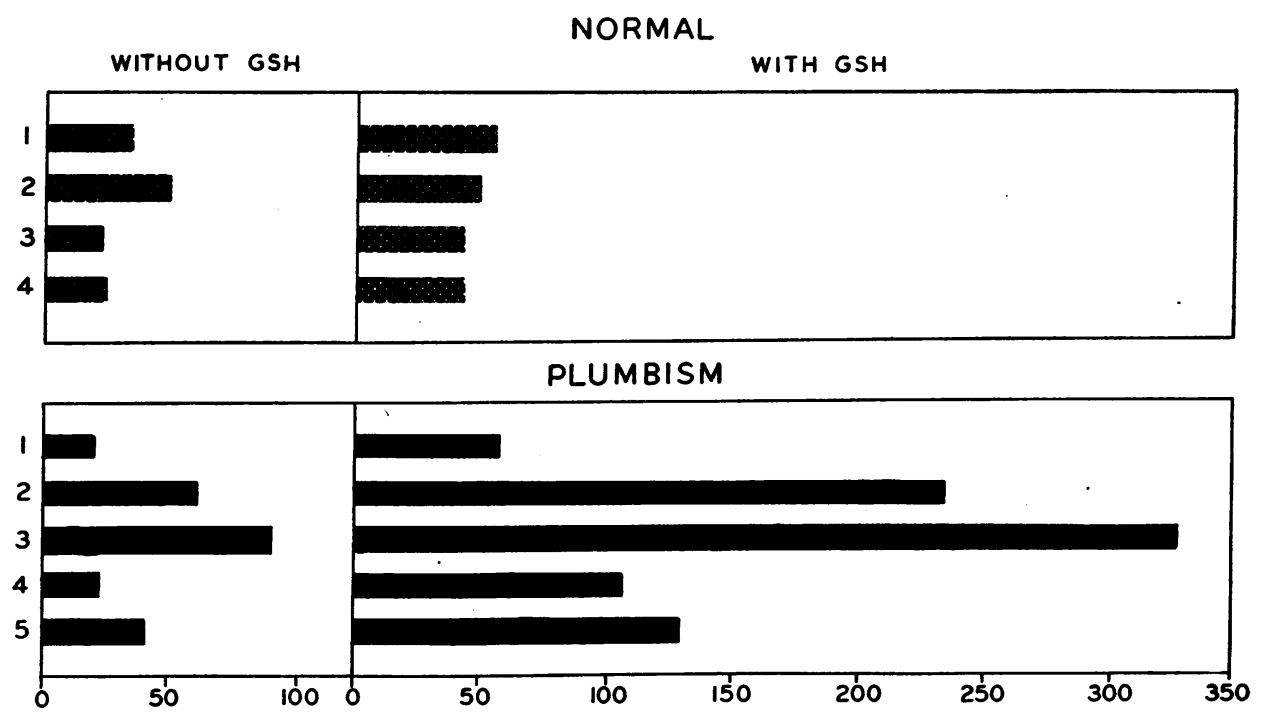

Fig. 4. $\delta$-AMINOLEVULINIC ACID DEHYDRASE ACTIVITY IN HEMOLYZED ERYTHROCYTES WITHOUT AND WITH GLUTATHIone. Activity is given in micromole $\times 10^{-8}$ of porphobilinogen per hour of incubation per milliliter of packed erythrocytes. 
per $100 \mathrm{ml}$ erythrocytes and a range of 67 to $\mathrm{ml}$ erythrocytes, with a range of 0 to $416 \mu \mathrm{g}$. $1,433 \mu \mathrm{g}$. The lead-poisoned erythrocytes pro- There was no significant protoporphyrin producduced the least amount of coproporphyrin. The mean of the determined values was $259 \mu \mathrm{g}$ per 100 tion in any of the three groups.

Comparison of results in the three groups is

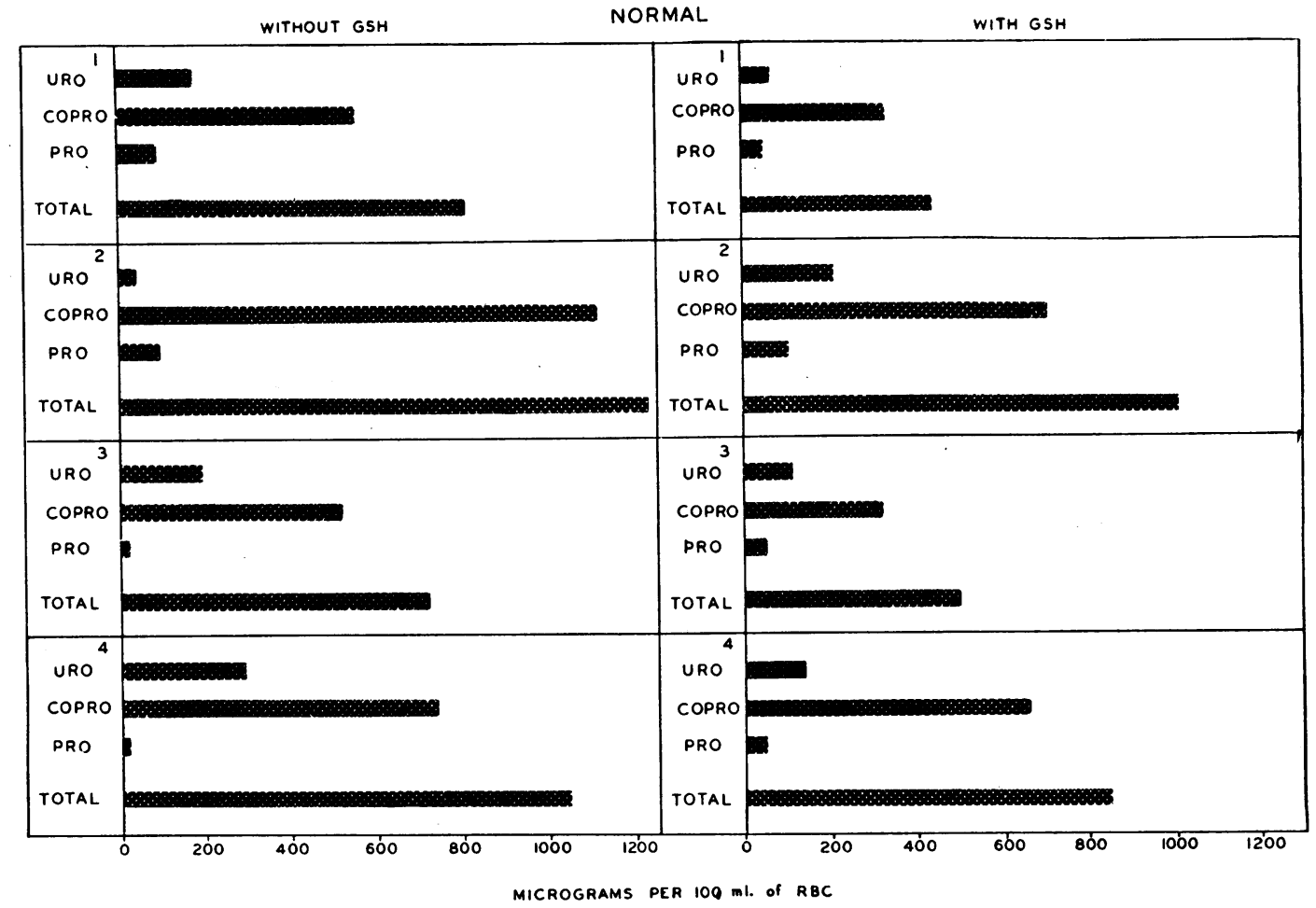

PORPHYRIN SYNTHESIS-PLUMBISM

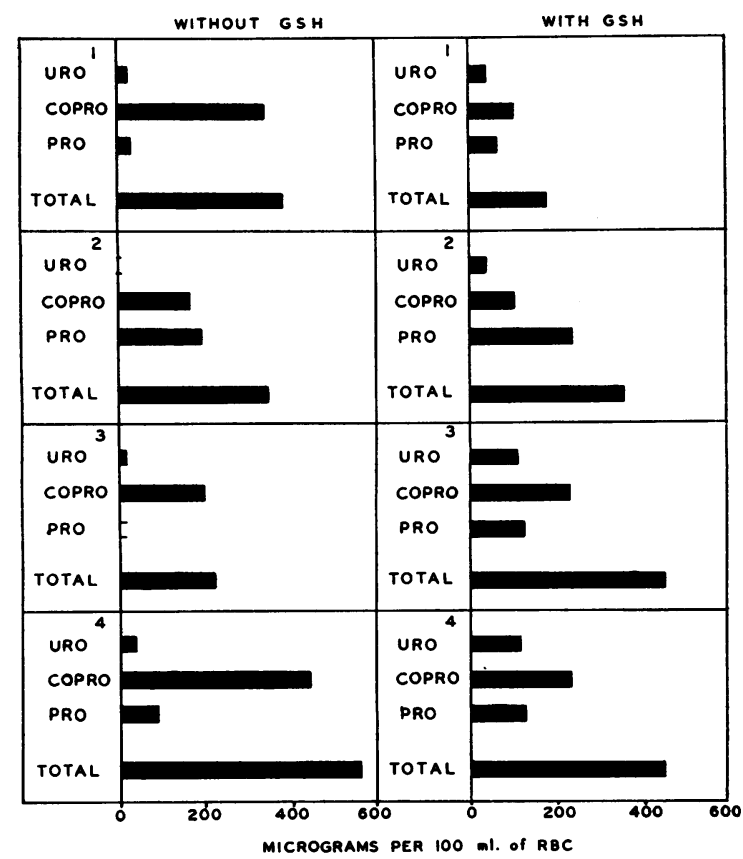

Fig. 5. PorPhyrin SYNTHESIS Without AND WITH GLUTATHIONE. 
presented graphically in Figure 3 . Under the conditions of these experiments, erythrocytes from normal persons were found capable of significantly greater stimulation of uroporphyrin and coproporphyrin synthesis than lead-poisoned erythrocytes ( $\mathrm{p}<.001$ and $<.05$, respectively), and of a significantly greater stimulation of uroporphyrin synthesis than iron-deficient erythrocytes $(p<.05)$. The only other significant difference shown in Figure 3 is that between the uroporphyrin synthesis of lead-poisoned and iron-deficient cells $(\mathrm{p}<$ $.05)$.

Effect of glutathione on $\delta$-aminolerulinic acid dehydrase activity and porphyrin synthesis from $\delta$-aminolevulinic acid. $\delta$-Aminolevulinic acid dehydrase activity was determined in four normal subjects and in five patients with lead poisoning with and without the addition of glutathione to the incubation mixtures.

Enhancement of $\delta$-aminolevulinic acid dehydrase activity in the normal group was not significant. The mean activity without glutathione was 31 $\times 10^{-3} \mu$ mole porphobilinogen per $\mathrm{ml}$ packed erythrocytes per hour. This result cannot be compared with the normal mean previously expressed, since for this experiment, the hemolyzed cells were incubated for 1 hour at $37^{\circ} \mathrm{C}$ before the addition of substrate. The mean activity with glutathione added was $48 \times 10^{-3} \mu$ mole.

In the patients with plumbism, however, the effect of glutathione was striking. The mean activity without glutathione was $45 \times 10^{-3} \mu$ mole porphobilinogen and with it, $171 \times 10^{-3} \mu$ mole (Figure 4).

Porphyrin production from $\delta$-aminolevulinic acid with and without glutathione is shown in Figure 5. There was no significant change in porphyrin synthesis in either normal or leadpoisoned erythrocytes.

\section{DISCUSSION}

Deviations in porphyrin metabolism are known to occur in association with lead poisoning. Unusually large amounts of $\delta$-aminolevulinic acid (5, 31 ) and porphyrins (32) are found in the urine, and free erythrocyte porphyrins are markedly elevated $(2,33,34)$. It is most likely that these findings reflect defective heme biosynthesis rather than abnormalities in heme catabolism (4). Vari- ous mechanisms have been suggested for the deleterious effects of lead. One of the theories postulated suggests diminished enzyme activity in at least two points, one before the formation of $\delta$ aminolevulinic acid, and the second at the conversion of protoporphyrin to heme (21). Other theories suggested include: inhibition of the insertion of iron into protoporphyrin (34), impaired formation of protoporphyrin $(32,35)$, and abnormal activity of three different enzyme systems, i.e., one catalyzing the formation of coproporphyrin, the second responsible for converting copro- to protoporphyrin, and the third necessary for the insertion of iron into protoporphyrin to form heme (36).

The present study was directed at that part of the heme biosynthetic pathway between $\delta$-aminolevulinic acid and coproporphyrin. The findings indicate that in the lead-poisoned erythrocyte there is a reduction of activity of $\delta$-aminolevulinic acid dehydrase, the enzyme necessary for the conversion of $\delta$-aminolevulinic acid to porphobilinogen. Lead probably affects this enzyme by inactivating sulfhydryl groups necessary for its activity, since the defect was reversible by preactivation with glutathione, a potent source of sulfhydryl groups. This is not a new concept, and was suggested by Granick and Mauzerall as the explanation for the inhibition of protoporphyrin synthesis from $\delta$ aminolevulinic acid in the presence of lead (37).

The data also indicate that in the lead-poisoned erythrocyte, the rate of synthesis of uroporphyrin and coproporphyrin from porphobilinogen is decreased. Preincubation with glutathione did not improve the low yield of porphyrins synthesized from $\delta$-aminolevulinic acid, although it did augment the synthesis of porphobilinogen. This may mean that the poor porphyrin synthesis found in lead poisoning is not entirely the result of lack of available porphobilinogen. It seems more likely that lead was responsible for the inhibition of porphyrin synthesis at two or more sequential steps between $\delta$-aminolevulinic acid and coproporphyrin. Granick and Mauzerall (37) and Dresel and Falk (38) reported only slight diminution of protoporphyrin synthesis from porphobilinogen in the presence of lead. This would seem to indicate that the inhibitory effect of lead between porphobilinogen and protoporphyrin is minor compared with its effect on $\delta$-aminolevulinic acid dehydrase. 
The marked increase in free erythrocyte porphyrins in plumbism and the obvious decrease in in vitro porphyrin production appears paradoxical only if it is assumed that high levels of free erythrocyte porphyrin can occur only as a result of increased porphyrin synthesis. The findings can be as well explained in the presence of decreased total porphyrin synthesis if there is a major block at the point of incorporation of iron into protoporphyrin to form heme. Such a block has in fact been demonstrated (39).

Normally most of the porphyrin produced in the erythrocyte is incorporated into the heme portion of the hemoglobin molecule. Since about $35 \mathrm{~g}$ of hemoglobin is normally present in $100 \mathrm{ml}$ of erythrocytes and each gram of hemoglobin contains $35 \mathrm{mg}$ porphyrin, there is roughly $1 \mathrm{~g}$ porphyrin bound in hemoglobin. Also, this volume of erythrocytes would contain 60 to $100 \mu \mathrm{g}$ free porphyrin. In lead poisoning, although the free erythrocyte porphyrins are usually greatly increased, this is only a small fraction of the total porphyrins normally produced. In our patients with plumbism, for example, the mean hemoglobin content was $27 \mathrm{~g}$ per $100 \mathrm{ml}$ erythrocytes, a deficit of $8 \mathrm{~g}$ hemoglobin or $245,000 \mu \mathrm{g}$ porphyrin. The mean free porphyrin was increased to $1,665 \mu \mathrm{g}$ per $100 \mathrm{ml}$ erythrocytes, leaving a net deficit of $243,335 \mu \mathrm{g}$ of total porphyrin synthesized. In vivo, therefore, this analysis revealed a marked drop in total synthesis with a pileup of free porphyrins.

These experiments have demonstrated deficient $\delta$-aminolevulinic acid dehydrase activity in the lead-poisoned erythrocyte. Increases in serum and urinary $\delta$-aminolevulinic acid (5) can, at least in part, be explained by decreased activity of this enzyme. It does not necessarily follow, however, that this is the rate-limiting block in heme biosynthesis accounting for the anemia of lead poisoning. Evidence has been presented by other investigators that would seem to indicate that an earlier step, leading to the synthesis of $\delta$-aminolevulinic acid, is much more sensitive to the effects of lead (38).

In the erythrocytes of patients with iron-deficiency anemia, $\delta$-aminolevulinic acid dehydrase was normal. The synthesis of porphyrins from $\delta$-aminolevulinic acid, however, especially uroporphyrin, was significantly diminished. This may indicate interference with porphobilinogen deami- nase or isomerase activity in iron-deficiency anemia.

\section{SUMMARY}

1. In the lead-poisoned erythrocyte, the activity of $\delta$-aminolevulinic acid dehydrase, the enzyme necessary for conversion of $\delta$-aminolevulinic acid to porphobilinogen, is decreased.

2. In vitro porphyrin production from $\delta$-aminolevulinic acid is markedly diminished in lead poisoning.

3 . In the lead-poisoned erythrocyte, the $\delta$ aminolevulinic acid dehydrase deficit can be reversed by preactivating the incubation mixtures with glutathione; however, glutathione preincubation does not augment in vitro porphyrin production from $\delta$-aminolevulinic acid. This seems to indicate a defect in the biosynthetic pathway for heme in the sequence beyond porphobilinogen.

4. In erythrocytes in iron-deficiency anemia. $\delta$-aminolevulinic acid dehydrase activity is normal. In vitro porphyrin synthesis is diminished.

\section{ACKNOWLEDGMENTS}

We wish to express our gratitude to Drs. Granick and Mauzerall of the Rockefeller Institute for Medical Research for their expert guidance. We also wish to thank Dr. Peter Nemenyi of the Department of Environmental Medicine, State University of New York, Downstate Medical Center, for the statistical analyses.

\section{REFERENCES}

1. Gould, S. E., H. J. Kullman, and H. A. Shecket. Effect of lead therapy on blood cells of cancer patients. Amer. J. med. Sci. 1937, 194, 304.

2. Rubino, G. F., E. Pagliardi, V. Prato, and E. Giangrandi. Erythrocyte copper and porphyrins in lead poisoning. Brit. J. Haemat. 1958, 4, 103.

3. Bessis, M. C., and J. Breton-Gorius. Ferratin and ferruginous micelles in normal erythroblasts and hypochromic hypersideremic anemias. Blood 1959, 14, 423.

4. Grinstein, M., H. M. Wikoff, R. Pimenta de Mello, and C. J. Watson. Isotopic studies of porphyrin and hemoglobin metabolism. II. The biosynthesis of coproporphyrin III in experimental lead poisoning. J. biol. Chem. 1950, 182, 723.

5. Haeger-Aronsen, B. Studies on urinary excretion of $\delta$-aminolaevulic acid and other haem precursors in lead workers and lead-intoxicated rabbits. Scand. J. clin. Lab. Invest. 1960, 12, suppl. 47.

6. Shemin, D., and D. Rittenberg. The utilization of glycine for the synthesis of a porphyrin. J. biol. Chem. 1945, 159, 567. 
7. Shemin, D., and D. Rittenberg. The biological utilization of glycine for the synthesis of the protoporphyrin of hemoglobin. J. biol. Chem. 1946, 166, 621.

8. Altman, K. I., G. W. Casarett, R. E. Masters, T. R. Noonan, and K. Salomon. Hemoglobin synthesis from glycine labeled with radioactive carbon in its $\alpha$-carbon atom. J. biol. Chem. 1948, 176, 319.

9. Shemin, D., and S. Kumin. The mechanism of porphyrin formation. The formation of a succinyl intermediate from succinate. J. biol. Chem. 1952, 198, 827.

10. Shemin, D., and C. S. Russell. $\delta$-Aminolevulinic acid, its role in the biosynthesis of porphyrins and purines. J. Amer. chem. Soc. 1953, 75, 4873 .

11. Cookson, G. H., and C. Rimington. Porphobilinogen. Biochem. J. 1954, 57, 476.

12. Dresel, E. I. B., and E. Falk. Conversion of $\delta$-aminolaevulinic acid to porphobilinogen in a tissue system. Nature (Lond.) 1953, 172, 1185.

13. Granick, S. Enzymatic conversion of $\delta$-aminolevulinic acid to porphobilinogen. Science 1954, 120, 1105.

14. Gibson, K. D., A. Neuberger, and J. J. Scott. The enzymatic conversion of $\delta$-aminolaevulic acid to porphobilinogen (abstract). Biochem. J. 1954, 58, xli.

15. Bogorad, L., and S. Granick. The enzymatic synthesis of porphyrins from porphobilinogen. Proc. nat. Acad. Sci. (Wash.) 1953, 39, 1176.

16. Falk, J. E., E. I. B. Dresel, and C. Rimington. Porphobilinogen as a porphyrin precursor, and interconversion of porphyrins, in a tissue system. Nature (Lond.) 1953, 172, 292.

17. Granick, S., and D. Mauzerall. Porphyrin biosynthesis in erythrocytes. II. Enzymes converting $\delta$-aminolevulinic acid to coproporphyrinogen. $\mathrm{J}$. biol. Chem. 1958, 232, 1119.

18. Dresel, E. I. B., and J. E. Falk. Studies on the biosynthesis of blood pigments. 5. Intermediates in haem biosynthesis. Biochem. J. 1956, 63, 388.

19. Mauzerall, D., and S. Granick. Porphyrin biosynthesis in erythrocytes. III. Uroporphyrinogen and its decarboxylase. J. biol. Chem. 1958, 232, 1141.

20. Grinstein, M., R. M. Bannerman, and C. V. Moore. The utilization of protoporphyrin 9 in heme synthesis. Blood 1959, 14, 476.

21. Goldberg, A., H. Ashenbrucker, G. E. Cartwright, and M. M. Wintrobe. Studies in the biosynthesis of heme in vitro by avian erythrocytes. Blood 1956, 11, 821.

22. Schwartz, H. C., G. E. Cartwright, E. L. Smith, and M. M. Wintrobe. Studies on the biosynthesis of heme from iron and protoporphyrin. Blood 1959, 14, 486.

23. Labbe, R. F. An enzyme which catalyzes the insertion of iron into protoporphyrin. Biochim. biophys. Acta (Amst.) 1959, 31, 589.
24. London, I. M., D. Shemin, and D. Rittenberg. The in vitro synthesis of heme in the human red blood cell of sickle cell anemia. J. biol. Chem. 1948, 173, 797.

25. Schmid, R., and D. Shemin. The enzymatic formation of porphobilinogen from $\delta$-aminolevulinic acid and its conversion to haem (abstract). J. clin. Invest. 1955, 34, 911.

26. Schwartz, S., and H. M. Wikoff. The relation of erythrocyte coproporphyrin and protoporphyrin to erythropoiesis. J. biol. Chem. 1952, 194, 563.

27. Dresel, E. I. B., and B. E. Tooth. Solubility of uroporphyrin I in ethyl acetate. Nature (Lond.) 1954, 174, 271.

28. Dresel, E. I. B., and J. E. Falk. Studies on the biosynthesis of blood pigments. 2. Haem and porphyrin formation in intact chicken erythrocytes. Biochem. J. 1956, 63, 72.

29. Schwartz, S., L. Zieve, and C. J. Watson. Improved method for the determination of urinary coproporphyrin and evaluation of factors influencing the analysis. J. Lab. clin. Med. 1951, 37, 843.

30. Gibson, K. D., A. Neuberger, and J. J. Scott. The purification and properties of $\delta$-aminolaevulinic acid dehydrase. Biochem. J. 1955, 61, 618.

31. Maloof, C. C. Role of porphyrins in occupational diseases. I. Significance of coproporphyrinuria in lead workers. Arch. industr. Hyg. 1950, 1, 296.

32. Rimington, C. An enzymic theory of hemopoiesis. C. R. Lab. Carlsberg (Copenhagen) 1937, 22, 454.

33. Watson, R. J., E. Decker, and H. C. Lichtman. Hematologic studies of children with lead poisoning. Pediatrics 1958, 21, 40.

34. Watson, C. J. The erythrocyte coproporphyrin. Variation in respect to erythrocyte protoporphyrin and reticulocytes in certain of the anemias. Arch. intern. Med. 1950, 86, 797.

35. Kench, J. E., A. E. Gillam, and R. E. Lane. Haemopoiesis in lead poisoning. Biochem. J. 1942, 36, 384.

36. Eriksen, L. Lead intoxication: I. The effect of lead on the in vitro biosynthesis of heme and free erythrocyte porphyrins. Scand. J. clin. Lab. Invest. $1955,7,80$.

37. Granick, S., and D. Mauzerall. The metabolism of heme and chlorophyll in Metabolic Pathways, D. M. Greenberg, Ed. New York, Academic Press, 1960, vol. 2, p. 603.

38. Dresel, E. I. B., and J. E. Falk. Studies on the biosynthesis of blood pigments. 3. Haem and porphyrin formation from $\delta$-aminolaevulic acid and from porphobilinogen in haemolysed chicken erythrocytes. Biochem. J. 1956, 63, 80.

39. Jandl, J. H., J. K. Inman, R. L. Simmons, and D. W. Allen. Transfer of iron from serum ironbinding protein to human reticulocytes. J. clin. Invest. 1959, 38, 161. 